\title{
PENINGKATAN PERILAKU PSK MENGGUNAKAN BUKU SAKU DALAM PENCEGAHAN DAN PENANGANAN PENYAKIT MENULAR/ HIV DI GUNUNG KEMUKUS KABUPATEN SRAGEN
}

\author{
Suyanto, Dwi Susi Haryati \\ Kementerian Kesehatan Politeknik Kesehatan Surakarta Jurusan Keperawatan
}

\begin{abstract}
Pocket Books, PSK, Mount Kemukus. Some of the main reasons Woman Being prostitution as well as economic factors. To PSK is a choice that has a lot of risk one is contracting sexually transmitted diseases/ HIV and they have a big share in the spread of the disease. Thus there is no reason the prostitutes must have behaviors that can prevent and make the handling of infectious diseases/ HIV as a result the risk of becoming prostitutes. But until now they have not done well with their proven PSK contract some sexually transmitted diseases.Given the rise of the behavior before and after using a pocket book in the prevention and treatment of sexually transmitted diseases/ HIV PSK Mount Kemukus Sragen. This study was a quasi-experimental, using a pre-post test approach using a questionnaire. Enelitian population are the prostitutes in Mount Kemukus Sragen with samplel number as many as 30 people. Furthermore, the analysis using quadratic Kai Test (Chi Square) with the aid of a computer. The results showed that the behavior of infectious disease prevention / HIVsebelum and after given pocket book while there is no difference to the behavior of the handling of infectious diseases/ HIV there are significant differences. Based on these results the researchers advised to maintain good handling practices already and do efforts to improve prevention behaviors.
\end{abstract}

Keywords: Pocket Books, PSK, Mount Kemukus

Abstrak : Buku saku, PSK, Gunung Kemukus. Beberapa Alasan utama Wanita Menjadi PSK karena terpaksa dan dipaksa serta faktor ekonomi. Menjadi pekerja seks komersial adalah sebuah pilihan yang memiliki banyak resiko salah satunya adalah tertular penyakit seksual/ HIV dan mereka memiliki andil yang besar dalam penyebaran penyakit tersebut. Dengan demikian tidak ada alasan para PSK harus memiliki perilaku yang dapat mencegah dan melakukan penanganan penyakit menular/HIV sebagai akibat resiko menjadi PSK. Tetapi hingga saat ini masih belum dilakukan dengan baik dengan adanya beberapa PSK yang terbukti memngidap penyakit menular seksual.Tujuan Umum: Melihat peningkatan perilaku sebelum dan sesudah menggunakan buku saku dalam pencegahan dan penanganan penyakit seksual menular/ HIV PSK di Gunung Kemukus Kabupaten Sragen. Desain Penelitian: Desain penelitian ini adalah kuasi eksperimen, dengan menggunakan pendekatan pre-post test menggunakan kuesioner. Populasi enelitian ini adalah para PSK di Gunung Kemukus kabupaten Sragen dengan jumlah samplel sebanyak 30 orang. Selanjutnya dilakukan dianalisa menggunakan Uji Kai kuadrat (Chi Square) dengan bantuan komputer. Hasil penelitian menunjukkan bahwa perilaku pencegahan penyakit menular/ HIVsebelum dan sesudah diberikan buku saku tidak terdapat perbedaan sedangkan untuk perilaku penanganan penyakit 
menular/HIV terdapat perbedaan yang signifikan. Berdasarkan hasil tersebut maka peneliti menyarankan untuk mempertahankan perilaku penanganan yang sudah baik dan melakukan upaya meningkatkan perilaku pencegahan.

Kata Kunci : Buku saku, PSK, Gunung Kemukus

\section{PENDAHULUAN}

Perkembangan ilmu pengetahuan dan teknologi di era globalisasi sekarang ini sangat mendukung dalam kehidupan manusia seperti ilmu kesehatan yang cepat bekembang mulai dari peralatan ataupun teori sehingga mendorong para pengguna untuk bisa memiliki dan memahami wawasan serta ilmu pengetahuan tersebut.

Terkait dengan perkembangan ilmu kesehatan, maka salah satu ilmu yaitu kesehatan reproduksi berkembang dan perlu terus dikembangkan dan dikuasai oleh tenaga kesehatan seperti perawat. Ilmu ini juga harus dimiliki oleh wanita sebagai ibu atau calon ibu dari anak-anaknya demi kesehatan dan kesejahteraan keluarga.

Tetapi dalam beberapa kondisi seorang wanita karena berbagai alasan menjadi PSK (Pekerja Seks Komersial) yaitu seorang wanita yang menjual tubuhnya kepada laki-laki selain suaminya jika telah bersuami yaitu karena dipaksa, namun ada sebagian wanita yang menyukai pekerjaan ini, alasan lain yaitu karena faktor ekonomi.

Salah satu tempat para PSK melakukan aktivitasnya yaitu di daerah Gunung Kemukus Kabupaten Sragen. Hal tersebut terjadi karena adanya keyakinan sebagian masyarakat, bahwa makam Pangeran Samodro dijadikan tempat ngalap berkah (mencari keberuntungan) yang disertai ritual seks. Hal tersebut ditepis oleh Pemerintah Daerah kabupaten Sragen dan menganggap hal itu tidak benar. Keyakinan yang salah itu harus diluruskan. Berziarah ke Makam Pangeran Samudro atau Gunung Kemukus hanyalah kegiatan ritual untuk mengingat jasa Pangeran Samudro. Fenomena Gunung Kemukus yang berada di Dukuh Doyong, Kecamatan Miri, Kabupaten Sragen seringkali dipahami untuk mencari pesugihan. Hal ini dinilai pemahaman yang salah. Mitos berkembang di tengah masyarakat, apabila ingin ngalap berkah, atau permohonannya terkabul, peziarah Makam Pangeran Samudro harus melakukan ritual berhubungan intim dengan lawan jenis, bukan suami atau istri, harus diluruskan.

Berdasarkan hasil wawancara yang dilakukan oleh Sulistyowati tahun 2014, didapatkan data bahwa dari 30 PSK terdapat 20 PSK $(80 \%)$ sudah mempunyai suami. Hal tersebut akan menjadi permasalahan kesehatan reproduksi bagi PSK tersebut, suami dan anak anaknya nanti.

Untuk itu maka Kementrian Kesehatan RI dalam menyusun prioritas Program Kesehatan Reproduksi salah satunya adalah pencegahan dan penanganan penyakit menular seksual termasuk HIV. Hal tersebut sangat berkenaan dengan kondisi para PSK di Gunung Kemukus sebab meskipun praktek prostitusi didaerah Gunung Kemukus telah ditutup secara resmi oleh Pemerintah Daerah Kabupaten Sragen, tetapi praktek prostitusi masih berlangsung hingga saat ini. Hal ini akan membuat masalah kesehatan reproduksi khususnya pencegahan dan penanganan 
penyakit menular seksual termasuk HIV akan tidak terkontrol sebab Dinas Kesehatan Kabupaten Sragen sudah tidak lagi melaksanakan kegiatan tersebut karena telah resmi ditutup.

Berdasarkan uraian di atas maka peneliti tertarik untuk melakukan penelitian tentang peningkatan perilaku PSK menggunakan buku saku dalam pencegahan dan penanganan penyakit menular/ HIV di Gunung Kemukus Kabupaten Sragen.

\section{METODE PENELITIAN}

Desain penelitian ini adalah kuasi eksperimen, dengan menggunakan pendekatan pre dan post test yaitu dilakukan pengukuran sebelum dan sesudah perlakuan.

Populasi sumber adalah semua PSK (pekerja seks komersial) di gunung Kemukus. Teknik pengambilan sampel di lakukan pada PSK di Gunung Kemukus dalam penelitian ini adalah secara purposive sampling sebanyak 28 orang dan yang bersedia melakukan pemeriksaan laboratorium sebanyak 28 orang. Waktu penelitian yang dipergunakan selama 11 bulan, dimulai pada bulan Februari sampai dengan November 2016.Analisa hasil penelitian dengan menggunakan uji Chi Square.

\section{HASIL PENELITIAN}

Tabel 1

Karakteristik Responden Berdasarkan Usia Dan Status Perkawinan

\begin{tabular}{lccccccc}
\hline \multicolumn{1}{c}{ Usia } & \multicolumn{2}{c}{$<\mathbf{1 8}$} & \multicolumn{1}{c}{$\mathbf{1 8}$} & $\mathbf{- 3 5}$ & \multicolumn{2}{c}{$>\mathbf{3 5}$} & Total \\
$\begin{array}{lccccccc}\text { Status } \\
\text { perkawinan }\end{array}$ & $\mathrm{f}$ & $\%$ & $\mathrm{f}$ & $\%$ & $\mathrm{f}$ & $\%$ & \\
\hline Belum kawin & - & 0 & 0 & 0 & - & 0 & 0 \\
Kawin & 1 & 3 & 7 & 23 & 1 & 3 & 9 \\
Janda & 0 & 0 & 13 & 43 & 8 & 28 & 21 \\
Total & 1 & 3 & 20 & 66 & 9 & 31 & 30 \\
\hline
\end{tabular}

Terlihat bahwa sebagian besar 66 $\%$ usia responden antara 18-35 tahun dan status perkawinan terbesar janda yaitu $28 \%$

\section{Tabel 2}

Keluhan Responden Terhadap Gejala Penyakit Menular Seksual Responden

\begin{tabular}{lll}
\hline Keluhan & Jumlah & Persentase \\
\hline Ada keluhan & 19 & 63,3 \\
Tidak ada keluhan & 11 & 36,6 \\
Jumlah & 30 & 100 \\
\hline
\end{tabular}

Terlihat bahwa lebih dari separuh $63,3 \%$ (19 orang ) responden memiliki keluhan menderita gejala penyakit menular seksual

Tabel 3

\begin{tabular}{|c|c|c|c|}
\hline \multicolumn{4}{|c|}{$\begin{array}{c}\text { Hasil Pemeriksaan Laboratorium } \\
\text { Responden }\end{array}$} \\
\hline $\begin{array}{l}\text { Hasil } \\
\text { Pemeriksaan }\end{array}$ & GO & TPHA & $\begin{array}{c}\text { HIV } \\
\text { Ag/Ab }\end{array}$ \\
\hline Positif & 3 & 1 & 0 \\
\hline Negatif & 20 & 27 & 6 \\
\hline Jumlah & 23 & 28 & 6 \\
\hline
\end{tabular}
responden yang menjadi sampel dalam penelitian ini hanya 28 orang yang bersedia untuk dilakukan pemeriksaan laboratorium dengan perincian sebagai berikut: Untuk pemeriksaan GO hanya dilakukan terhadap 23 orang responden sedangkan 5 orang tidak dilakukan pemeriksaan karena sedang mengalami menstruasi. Kemudian pemeriksaan TPHA untuk penyakit sifilis dilakukan pada 6 responden yang bersedia saat itu.

Tabel 4

Perilaku Pencegahan Penularan penyakit menular HIV sebelum Diberikan Buku Saku

\begin{tabular}{lll}
\hline Perilaku & Jumlah & Persentase \\
\hline Baik & 1 & 3,3 \\
Sedang & 13 & 43,3 \\
Buruk & 16 & 53,3 \\
Jumlah & 30 & 100 \\
\hline
\end{tabular}


Berdasarkan tabel 4 terlihat bahwa sebelum diberikan buku saku lebih dari separuh 53,3\% (16 orang) perilaku pencegahan penularan penyakit menular/ HIV para responden buruk dan hanya 1 orang saja yang baik.

\section{Tabel 5}

Perilaku Pencegahan Penularan Penyakit Menular HIV Sesudah Diberikan Buku Saku

\begin{tabular}{lll}
\hline Perilaku & Jumlah & Persentase \\
\hline Baik & 12 & 40 \\
Sedang & 17 & 56,7 \\
Buruk & 1 & 3,3 \\
Jumlah & 30 & 100 \\
\hline
\end{tabular}

Tabel 5 memperlihatkan bahwa perilaku responden setelah diberi buku saku dalam pencegahan penularan penyakit menular/HIV sebagian besar yaitu $56,7 \%$ atau 17 orang berkategori sedang.

\section{Tabel 6}

Perilaku Penanganan Penularan Penyakit Menular HIV Sebelum Diberikan Buku Saku

\begin{tabular}{lll}
\hline Perilaku & Jumlah & Persentase \\
\hline Baik & 6 & 20 \\
Sedang & 11 & 36,7 \\
Buruk & 13 & 43,3 \\
Jumlah & 30 & 100 \\
\hline
\end{tabular}

Terlihat bahwa sebelum diberikan buku saku lebih dari separuh yaitu 53,3\% (16 orang) perilaku pencegahan penularan penyakit menular/ HIV para responden buruk dan hanya 1 orang saja yang baik.

\section{Tabel 7}

Perilaku Penanganan Penularan Penyakit Menular HIV Sesudah Diberikan Buku Saku

\begin{tabular}{lll}
\hline Perilaku & Jumlah & Persentase \\
\hline Baik & 9 & 30 \\
Sedang & 11 & 36 \\
Buruk & 10 & 33,3 \\
Jumlah & 30 & 100 \\
\hline
\end{tabular}

Berdasarkan tabel 7 diketahui bahwa sesudah diberikan buku saku perilaku pencegahan penularan penyakit menular/HIV para responden yang berkategori buruk dan sedang hampir sama dan yang berkategorik baik hanya 9 orang saja.

Tabel 8

Perilaku Responden Sebelum Dan Sesudah Diberikan Buku Saku Dalam Pencegahan Penularan Penyakit Menular/ HIV

\begin{tabular}{|c|c|c|c|c|c|c|c|c|c|}
\hline \multirow{3}{*}{$\begin{array}{l}\text { Perilaku } \\
\text { pencegahan }\end{array}$} & \multicolumn{6}{|c|}{ Sesudah pemberian buku saku } & \multicolumn{2}{|c|}{ Total } & \multirow{3}{*}{$\begin{array}{l}\text { p. } \\
\text { val } \\
\text { ue }\end{array}$} \\
\hline & \multicolumn{2}{|c|}{ Baik } & \multicolumn{2}{|c|}{ sedang } & \multicolumn{2}{|c|}{ buruk } & \multirow[b]{2}{*}{$\mathrm{n}$} & \multirow[b]{2}{*}{$\%$} & \\
\hline & & $\%$ & $\mathrm{n}$ & $\%$ & $\mathrm{n}$ & $\%$ & & & \\
\hline Baik & 1 & 8,3 & 0 & 0 & 0 & 0 & 1 & 3,3 & 0,11 \\
\hline Sedang & 8 & $\begin{array}{l}66, \\
7\end{array}$ & 5 & 29,4 & 0 & 0 & 13 & 43,3 & 8 \\
\hline Buruk & 3 & 25 & 12 & 70,6 & 1 & 3,3 & 16 & 53,3 & \\
\hline Jumlah & 12 & 40 & 17 & 56,7 & 1 & 3,3 & 30 & 100 & \\
\hline
\end{tabular}

Terlihat bahwa perilaku pencegahan penularan penyakit menular /HIV sebelum dan sesudah diberi buku saku memiliki nilai $\mathrm{p}$ value $0,118>0,05$. Dengan demikian berarti tidak memiliki perbedaan antara sebelum dan sesudah diberikan buku saku.

Tabel 9

Perilaku Responden Sebelum Dan Sesudah Diberikan Buku Saku Dalam Penanganan Penularan Penyakit Menular/HIV

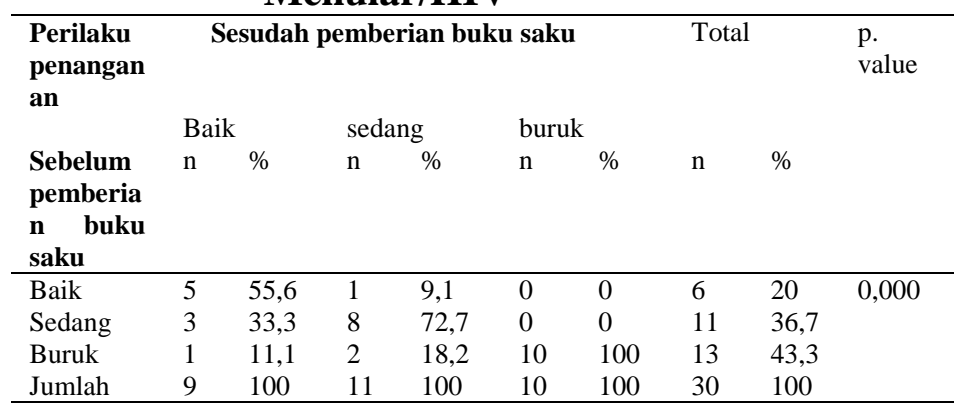

Berdasarkan tabel 9 terlihat bahwa perilaku penanganan penularan penyakit 
menular /HIV sebelum dan sesudah diberi buku saku memiliki nilai $\mathrm{p}$ value $0,00<$ 0,05 . Dengan demikian berarti memiliki perbedaan yang signifikan antara sebelum dan sesudah diberikan buku saku.

\section{PEMBAHASAN}

Pekerja Seks Komersial atau yang sering disebut PSK adalah seorang wanita yang menjual tubuhnya kepada laki-laki yang bukan suaminya dengan berbagai macam alasan dan latar belakang. Alasan menjadi PSK antara lain seperti alasan faktor ekonomi, ajakan teman untuk berpetualang dan rasa ingin tahu.

Selain itu alasan seseorang menjadi PSK yaitu menjadi korban jebakan dan dipaksa oleh majikan tempat bekerja atau juga dipaksa oleh orang terdekat seperti suami. Faktor lain yang menyebabkan seseorang menjadi PSK adalah akibat kekerasan seksual seperti pemerkosaan yang dilakukan oleh orang dekat dan yang saat ini menjadi kecenderungan adalah karena tuntutan gaya hidup modern sehingga seorang wanita sanggup menjual dirinya kepada laki laki lain demi uang.

Pilihan pekerjaan yang dilakukan oleh PSK memiliki berbagai beberapa resiko. Resiko terbesar yang harus ditanggung oleh PSK adalah tertular penyakit seksual yang paling sering ditemukan di Indonesia saat ini seperti Gonore (GO), Sifilis (raja singa) dan HIV/AIDS. Sehingga Wanita Pekerja Seks merupakan kelompok risiko tinggi terkena penyakit menular/ HIV dan paling berpengaruh dalam penyebarannya.

Berdasarkan hasil analisa data yang telah peneliti lakukan diperoleh hasil bahwa perilaku pencegahan penyakit menular/HIV memiliki nilai $\mathrm{p}$ value 0,118 yang berarti lebih besar dari 0,05 .
Dengan demikian dapat ditarik kesimpulan bahwa tidak terdapat perbedaan perilaku dalam pencegahan penyakit menular/HIV sebelum dan sesudah diberikan buku saku.

Perilaku yang belum menunjukan pencegahan yang lebih baik sebelum dan sesudah diberikan buku saku dapat dipahami mengingat bahwa perilaku pencegahan penyakit tidak hanya dituntut dari pihak PSK tetapi juga dari pihak lelaki. Meskipun PSK sudah berupaya melakukan pencegahan tetapi jika lelaki tidak mau maka pencegahan tidak dapat dilaksanakan dengan baik. Sebagai contoh dalam penggunaan kondom banyak lelaki yang tidak mau menggunakannya sebagaimana penelitian yang pernah dilakukan oleh Aryani dkk (2014) tentang perilaku pencegahan infeksi menular seksual wanita pekerja seksual kabupaten Tegal.

Hasil penelitian menunjukkan bahwa PSK pada dasarnya cukup aktif mencari informasi tentang penyakit menular/ HIV melalui teman, petugas kesehatan, media cetak dan elektronik. Sehingga hampir semua PSK merayu pelanggan untuk memakai kondom meskipun mereka masih belum benar dalam pencegahan penyakit menular/HIV yaitu dengan membersihkan vagina bagian dalam menggunakan antiseptik dan pasta gigi.

Berkenaan dengan pengetahuan PSK tentang penyakit menular/ HIV yang tidak diteliti, maka peneliti mengasumsikan bahwa PSK sudah terpapar informasi tentang penyakit menular HIV. Sebagaimana di teliti oleh Artika dkk (2009) tentang pengetahuan perempuan pekerja seks komersial mengenai penyakit menular seksual di desa Mertan kecamatan Bendosari 
kabupaten Sukoharjo diperoleh hasil bahwa pengetahuan perempuan pekerja seks komersial tentang penyakit menular/ HIV dalam kategori cukup baik sebanyak $70 \%$. Dengan demikian dapat dipahami bahwa pada dasarnya PSK berkeinginan melakukan pencegahan penyakit menular/ HIV tetapi pihak lelaki banyak yang tidak ikut serta melakukannya sehingga PSK tidk maksimal melakukan tindakan pencegahan penyakit menular/ HIV.

Berbeda dengan variabel perilaku pencegahan penularan penyakit menular/ HIV, maka variabel penanganan penyakit menular/ HIV memiliki hasil analisa data sebagai berikut. Perilaku penaganan penyakit menular/ HIV sebelum dan sesudah diberi buku saku memiliki Nilai $p$ value 0,00 yang berarti lebih kecil dari 0,05 . Dengan demikian dapat disimpulkan bahwa terdapat perbedaan yang signifikan perilaku dalam penanganan penyakit menular/ HIV sebelum dan sesudah diberikan buku saku.

Hasil penelitian yang demikian dapat dijelaskan berikut ini. Sesuai dengan manfaat buku saku sebagai salah satu media penyuluhan kesehatan, maka buku saku memiliki beberapa kelebihan seperti ringkas, jelas dan padat informasi serta informasi yang dapat diulang ulang jika sasaran belum mengerti.

Dengan demikian penggunaan buku saku diharapkan dapat menuntaskan permasalahan yang dihadapi petugas kesehatan dalam mengatasi perilaku PSK menangani penyakit menular/ HIV.

Penelitian yang menggunakan buku saku untuk meningkatkan pengetahuan pernah dilakukan pada siswa SMA oleh Sari dkk (2010) tentang studi efektifitas buku saku terhadap skor pengetahuan penyakit menular seksual pada siswa SMA Negeri Banyumas memperoleh hasil yaitu terdapat perbedaan skor pengetahuan siswa sebelum dan sesudah menerima buku saku. Terjadi peningkatan skor hasil pretest terhadap post test 1 sebesar 20,2\%, peningkatan skor hasil pretest terhadap post test 2 sebesar 31,2\%, dan peningkatan skor hasil post test 1 terhadap post test 2 sebesar 9,2\%, sehingga Hipotesis nol ditolak, yang berarti buku saku dapat meningkatkan skor pengetahuan tentang penyakit menular seksual pada siswa SMA Negeri Banyumas.

Dengan demikian dapat dipahami manfaat buku saku berdasarkan hasil penelitian yang menunjukkan bahwa terdapat perbedaan yang signifikan terhadap perilaku pencegahan penyakit menular/ HIV sebelum dan sesudah menggunakan buku saku oleh PSK di Gunung Kemukus Sragen.

\section{KESIMPULAN DAN SARAN}

Tidak terdapat perbedaan dalam peningkatan perilaku pencegahan penyakit menular/ HIV oleh para PSK di Gunung Kemukus sebelum dan sesudah diberikan buku saku.

Terdapat perbedaan yang signifikan dalam peningkatan perilaku penanganan penyakit menular/HIV oleh para PSK di Gunung Kemukus sebelum dan sesudah diberikan buku saku.

Berdasarkan kesimpulan yang telah dibuat, maka berikut ini peneliti sampaikan beberapa saran

Perilaku pencegahan penyakit menular/ HIV agar dapat terus diupayakan terutama pada pihak lelaki dengan cara selalu mengingatkan bahaya penyakit menular/ HIV jika tidak melakukan pencegahan seperti menggunakan kondom sebagai upaya alternatif pencegahan 
penyakit menular/ HIV perlu diupayakan promosi penggunaan kondom wanita.

Perilaku penanganan penyakit menular/ HIV yang telah dilakukan para PSK harus dipertahankan dan ditingkatkan menggunakan sarana pelayanan kesehatan beserta petugasnya.

Peneliti menyarakan untuk terus menggunakan media cetak seperti buku saku dalam meningkatkan perilaku pencegahan dan penanagan penyakit menular/ HIV.

Bagi peneliti lain disarankan untuk melajutkan penelitian ini dengan jumlah sampel yang lebih banyak dan metode yang lebih baik lagi.

\section{DAFTAR RUJUKAN}

Adebamowo CA, Emma R Ezeome ER, Ajuwon JA, Ogundiran TO. 2002. Survey of the knowledge, attitude and practice of Nigerian surgery trainees to $H I V$-infected persons and AIDS patients. http://www. biomedcentral. com/14712482/2/7. Diunduh 27 April 2012.

Anonim, 2011. Dasar-dasar kedokteran keluarga , http://usupress. usu.ac.id/ files/Dasar- dasar \% 20 \begin{tabular}{llll}
\hline Kedokteran $\%$ & 20 & Keluarga \\
\hline
\end{tabular} normal bab\%201. pdf. Diunduh 27 April 2012.

Artika (2009) Gambaran tingkat pengetahuan perempuan pekerja Seks komersial mengenai penyakit menular seksual di desa Mertan kecamatan Bendosari

Kabupaten Sukoharjo

$$
\begin{array}{ccc}
\text { Aryani } & \text { (2014) Gambaran } & \text { perilaku } \\
\text { pencegahan infeksi } & \text { menular } \\
\text { seksual wanita pekerja } & \text { seksual } \\
\text { Kabupaten Tegal } & &
\end{array}
$$

Azwar S. 2000. Sikap manusia teori dan pengukurannya. Jakarta. Pustaka Pelajar Offset.

Family Health Internasional. 2003. Attitudes and beliefs towards people living with HIV-AIDS. http:ww2.fhi.org/en/aids/ aidscap/ aidspubs/ behres / bcr4thheo. html. Diunduh tanggal 8 Maret 2012.

Kitaura H, Adachi N, Kobayashi K, Yamada T. 1997, Knowledge and attitudes of Japanese dental health care workers towards HIV-related disease. http: // www. sciencedirect. com/ science/ article/ pii/ S0300571296000309. Diunduh 27 April 2012

Kementerian Kesehatan Republik Indonesia, 2011, Pedoman Nasional penanganan Infeksi menular Seksual. http :// dinkessulsel. go.id/ new/ images/ pdf/ Peraturan. Diunduh 27 April 2012

Sari ( 2010) Studi efektifitas buku saku terhadap skor pengetahuan penyakit menular seksual pada siswa sma negeri banyumas

Suyanto.(2011). Metodologi dan Aplikkasi penelitian Keperawatan .Nuha Medika : Jogjakarta. 